\title{
SWOT Analysis of the Cultivation of Local International Talents in Higher Vocational Colleges in Hunan Province Under the "One Belt One Road" Strategy
}

\author{
Yihua Zeng1 ${ }^{*}$, Jianxiong Liu $^{2}$ \\ ${ }^{1}$ Loudi Vocational and Technical College, Loudi 417000, Hunan Province, China \\ ${ }^{2}$ Dongguan Vocational and Technical College, Dongguan, Guangdong Province, China \\ *Corresponding author: Yihua Zeng, 562641456@qq.com
}

\begin{abstract}
With the rapid development of international education, local international education has become a new trend. This study analyzes the strengths, weaknesses, opportunities, and challenges in the training of local international talents in higher vocational colleges under the "One Belt One Road" in Hunan Province to provide reference for Hunan's local internationalization.
\end{abstract}

Keywords: The Belt and Road Initiative; Hunan Province; Higher vocational colleges; Local international talent training; SWOT analysis

Publication date: December 2021; Online publication: January 25, 2022

\section{Introduction}

The Belt and Road Initiative was first proposed in 2013. The Action Plan for Innovation and Development of Higher Vocational Education (2015-2018), issued by the Ministry of Education in China, clearly urged higher vocational colleges to strengthen their educational cooperation with countries along the line and cultivate technical and skilled talents with international vision, who are familiar with international rules, as well as local talents that are needed by Chinese enterprises for overseas production and operation. This puts forward new requirements for the localization of international talent training in higher vocational colleges. In recent years, Hunan has accelerated the internationalization of vocational education. The 14th Five-Year Plan for the Development of Education in Hunan Province further proposed an action plan for the opening of education to build an open highland of education in Central China as well as support colleges and universities in carrying out in-depth cooperation with world-class universities for school operations and in enhancing their international influence ${ }^{[1]}$. Under new development situations, the majority of vocational educators should reflect on how higher vocational colleges in Hunan Province can comply with the requirements of modern times, accurately analyze the advantages and disadvantages, as well as seize the development opportunities and challenges. 
2. SWOT analysis of Hunan's vocational talent training under the strategy of "One Belt One Road"

\subsection{Strengths}

\subsubsection{Excellent education environment and high capital investment}

Educational foundation and capital investment have great impact on the quality of talent training. From the perspective of students, Hunan has always been a huge province for education, the threshold of its college entrance examination has always been high, and basic education has always been in the forefront. The quality of students in Hunan's higher vocational colleges is better than that of similar colleges in other provinces. From the perspective of education quality, among the 100 key higher vocational colleges in China, Hunan occupies five seats, which is leading the country. In terms of school-running, in 2020, there were 74 higher vocational colleges in Hunan, with a total of 702,900 students, and the education scale ranked among the top ten in China. From the perspective of education investment, Hunan Province has built five vocational education cities, with a total investment of 32.07 billion yuan, in which the education investment is at the middle and upper level ${ }^{[2]}$. It can be seen that Hunan Province has very rich educational resources. The overall education environment is excellent with a large educational scale. This is a major advantage for local international talent training in higher vocational colleges in Hunan Province.

\subsubsection{Diversified industrial types and strong school-enterprise cooperation}

Hunan Province is a strong manufacturing province. It is dominant in the fields of rail transit, construction machinery, and so on. In recent years, in order to better respond to the strategy of "One Belt One Road," the province has put forward the development strategy of "innovation leading, opening-up, and rising." Under this strategic layout, many high-quality enterprises are seizing the "One Belt One Road" strategy to seek development and command a position in foreign countries. At present, Hunan has more than 1,500 overseas enterprises registered under the Ministry of Commerce. These enterprises cover many fields, such as machinery manufacturing and rail transit, and span more than 80 countries and regions around the world. The cumulative foreign investment exceeds US $\$ 9.5$ billion, ranking first in the central region. With a large number of high-quality enterprises venturing abroad, foreign enterprises urgently need a large number of high-quality international talents, thus promoting the participation of multinational enterprises in international talent training and the support of higher vocational education from all aspects, including but not restricted to research and development, teaching and educational funding, etc. This plays an obvious role in promoting local international talent training.

\subsection{Weaknesses}

\subsubsection{Limited education funds and insufficient hardware}

Teaching facilities and educational equipment are important indicators for quality training. It has been long known that the education investment and tuition income of higher vocational colleges are lower than those of ordinary colleges and universities due to various reasons ${ }^{[4]}$. Higher vocational colleges usually focus on cultivating talents with applied and technical skills. Therefore, students need more experimental operations and technical training, thus putting forward higher requirements for training facilities and teaching equipment. It can be said that the quality of talent training is closely related to advanced training conditions and equipment. However, most of the funds for higher vocational education in Hunan are limited, only ensuring its basic operation. Besides, most of the training equipment is obsolete. In that sense, the training conditions of higher vocational colleges have not reached the international level. This situation brings difficulties to the cultivation of local international talents. 


\subsubsection{Lacking of international teachers and narrow vision in education}

Local international talent training is closely related to a team of high-quality international teachers. Only when teachers have international vision, understand the diverse cultures of the world, display advanced teaching concepts and diverse teaching methods, and are able to make good use of information-based teaching methods as well as carry out teaching in bilingual languages can students learn and understand the customs and human conditions of different countries and nationalities along with the latest professional and technical standards and requirements. This would ensure that students are able to quickly adapt to the needs of foreign or multinational enterprises upon graduation. At present, although many higher vocational colleges in Hunan have begun to send teachers abroad for training, the systems for teachers to study abroad are imperfect due to the late start and insufficient funds. In addition, the number and percentage of teachers who are studying abroad are low. Therefore, there are only a number of professional teachers with overseas learning and training experience who can teach bilingually. Most teachers lack international vision. Overall, the international level of teachers still does not meet the needs of local international education.

\subsubsection{Lacking overseas students and poor international cultural environment at campus}

A good international cultural environment has great impact on local international education. However, Hunan neither has border advantages nor economic open areas compared to other regions due to its location in the middle part of China. The level of educational internationalization is low, and it is not attractive to overseas students. There are only several foreign students in Hunan. In 2019, among the 71 higher vocational colleges in Hunan, only 14 higher vocational colleges were qualified to recruit overseas students, and only 339 full-time overseas students were enrolled, while the number of overseas students in the whole country had reached more than 17,000; the percentage of overseas students in Hunan was less than $0.2 \%$ of the country's total. The issue with higher vocational colleges is either they do not recruit overseas students or the number of college students who have been recruited from overseas is small. Therefore, the needs of local students to communicate with overseas students are not met. As a result, the international cultural environment at campus is poor, which may be a disadvantage to local international training.

\subsection{Opportunities}

\subsubsection{The Belt and Road Initiative}

As the "One Belt One Road" strategy continues to deepen, many enterprises in Hunan Province are joining hands with higher vocational colleges to venture abroad. They have built many factories along the line to achieve efficient operations. In this context, in order to meet the needs of international development, multinational enterprises and higher vocational colleges have jointly developed advanced technologies and equipment to provide good technical conditions for local international education in higher vocational colleges. In order to meet the talent needs of foreign enterprises, higher vocational colleges and multinational enterprises have cultivated local technical talents through the joint construction of schools and enterprises ${ }^{[4]}$. In order to improve the teaching effectiveness, many vocational education standards and curriculum standards have been developed and recognized by other countries. They do not only provide better teaching resources for local international education, but also accumulate international education experiences for local international education.

\subsubsection{The "Three Highlands and Four New Missions" strategy}

Since September 2020, Hunan is striving to promote the country's advanced manufacturing industry, scientific and technological innovation with core competitiveness, as well as the reform and opening-up of inland area. Therefore, the 12th Plenary Session of the 11th CPC Hunan Provincial Committee clearly 
proposed the implementation of the "Three Highlands and Four New Missions" strategy as the general outline in striving to build a new and modern Hunan. The proposal of the "Three Highlands and Four New Missions" strategy puts forward new requirements for its reform and opening-up. In order to build the "Three Highlands," Hunan Provincial Department of Education decided to begin the construction of vocational education highland in Hunan, cultivate a large number of high-quality technical and skilled talents with international vision, as well as give strong support in terms of fund investment and scientific research. This provides a good opportunity for the cultivation of local international talents in Hunan's higher vocational colleges.

\subsubsection{Rapid development of information education}

In response to the sudden emergence of COVID-19, the education industry has accelerated the process of information education. Schools have established a relatively comprehensive online education system, and the level of information education of teachers has also raised. The comprehensive information education system provides a good opportunity for the development of local international education. With good online education conditions, higher vocational colleges can cooperate with foreign educational institutions to purchase a certain amount of high-quality online education resources or invite foreign experts and scholars to teach online. These can easily turn the dream of enjoying high-quality international education resources at home into a reality and fulfill the desire of online learning as well as communication between local students and foreign students, so as to improve the quality of local international talent training.

\subsection{Challenges}

\subsubsection{Lacking geographical advantages}

Other than its own strength, economic level, and other factors, geographical location also has certain impact on education. Hunan Province is located in the inland of China. It is neither near the border nor belongs to the economic open zone. There is still a large gap in its openness, cultural level, and speed of economic development compared with the coastal areas. Hunan has no geographical advantages in the "One Belt One Road" strategy, and it does not receive any preferential treatment. Hunan is not among the 14 provinces that have signed the contract with the Ministry of Education to promote the construction of the "One Belt One Road" education cooperation. In that case, Hunan does not enjoy the substantive support policies from the Ministry of Education, including the two-way education and foreign-related education. This has limited Hunan's capabilities in running international schools and affected its level of internationalization, thus bringing greater challenges to Hunan's higher vocational education.

\subsubsection{Insufficient policy guidance}

The main body of the "One Belt and One Road" strategy is the government. In that case, policy guidance from the government has great influence on international education. The internationalization of higher education in Jiangsu, Tianjin, Yunnan, Guangxi, and other areas has developed rapidly in recent years, which is closely related to a series of international education incentives and support policies from the local government. For example, Jiangsu has issued an action plan, "Study in Jiangsu," and offered special scholarships; Tianjin's "Luban Workshop" is also led and guided by the government. However, the local governments in Hunan, from the provincial level to the municipal level, have insufficient understanding of the internationalization of higher education and weak policy guidance. At present, no special policies have been issued to promote the internationalization of higher education; in addition, no special funds have been arranged to support it. Therefore, international education is still relatively weak in Hunan Province, and the 
experience as well as level of its international education are not up to par, thus bringing huge challenges to its local international education.

\section{Conclusion}

Through SWOT analysis, higher vocational colleges can adopt different methods and strategies to carry out local international education in line with to their own reality. According to S-O strategies, schools can take advantage of the "One Belt One Road" strategy and the "Three Highlands and Four New Missions" strategy in Hunan, join hands with enterprises in Hunan to establish training schools or training centers overseas, as well as accumulate successful experience of international education. Meanwhile, they can also take advantage of the opportunity of the rapid development of information education, introduce foreign highquality education resources, and open a new chapter of local international education. Based on W-O strategies, higher vocational colleges in Hunan should strengthen cooperation with excellent enterprises according to the international market demand, jointly formulate and modify talent training programs, accelerate the research and development of international vocational education standards and curriculum standards, as well as improve the level of international curriculum construction. Other than that, they can also carry out online training and strengthen the communication between students and foreign teachers, in order to improve the overall international literacy of both teachers and students. According to T-S strategies, schools should make full use of their high-quality education resources, seize the opportunity to integrate education with industries, gain international education experiences from other local schools, focus on the top-level design of schools, as well as create an international brand of local vocational education. According to W-T strategies, schools should establish the concept of local internationalization, make full use of the government's policy in building a vocational education highland, strengthen the construction of experimental and training facilities, implement training plans for excellence and quality improvement, as well as strengthen their core values.

\section{Funding}

This study was funded by "The Research on the Training Strategy of Hunan Local Vocational Talents in Vocational Colleges Under the Strategy of 'One Belt, One Road' in Hunan Province" Project (Project Number: ZJGD2021130).

\section{Disclosure statement}

The authors declare that there is no conflict of interest.

\section{References}

[1] Yang H, Liu Y, Hu P, et al., 2020, The Research on the Training of International Talents in Higher Vocational Colleges. Occupation Technology, 19(10): 13-17.

[2] Chen Y, Liang C, 2019, Exploration of the Training Path of International Talents in Higher Vocational Colleges Under the Background of "One Belt and One Road". Occupation Technology, 18(9): 1-4.

[3] Liu Z, Zhang Y, 2020, Under the Background One Belt, One Road, Hunan Province Vocational Colleges International Talent Training Way Innovation Research. International Public Relations, 2020(6): 56-57.

[4] Sun W, Liu X, 2019, One Belt, One Road, The Background of Higher Vocational Colleges International Talent Training Research. Journal of Huaihai Institute of Technology (Humanities and Social Sciences), 17(04): 127-129. 